\title{
Revitalization of the damaged machine parts by hard facing as a way of saving funds
}

\author{
Vukić Lazić $^{1}$, Dušan Arsić ${ }^{1}$, Ružica Nikolić ${ }^{1,2}$, Milan Mutavžić ${ }^{3}$, Branislav Hadzima ${ }^{2}$ \\ ${ }^{1}$ Faculty of Engineering, University of Kragujevac, Sestre Janjić 6, 34000 Kragujevac,Serbia, vlazic@kg.ac.rs;dusan.arsic@ fink.rs \\ ${ }^{2}$ Research Center, University of Žilina, Univerzitna 1, 01026 Žilina, Slovakia, ruzicarnikolic@ yahoo.com;branislav.hadzima@ rc.uniza.sk \\ ${ }^{3}$ High Technical School, 24. Novembernn, 38218 Leposavić, Serbia, cmz@ fink.rs
}

\begin{abstract}
The objective of the research, presented in this paper; was to demonstrate the superiority of the hard facing as the revitalization technology of various damaged machine parts. The analysis of the two different revitalization methods of the damaged machine parts is presented - the replacement of the damaged part by the new - spare part and reparation by hard facing. The comparison is done on the example of hard facing and replacing of damaged loader's teeth. The paper presents a method for calculating costs of the two revitalization technologies based on their profitability and their comparison. That method could be applied for similar calculations for any machine part, with smallest or no adjustments. The paper presents a verification of advantage of applying the hard facing as the machine parts reparatory technology with respect to the other revitalization technology. The savings realized by application of hard facing reparation of the loader's teeth reach $73.5 \%$ for one set of teeth and 82.40per annum of the costs for purchasing the new spare parts. The analysis was conducted under an assumption that organization of the maintenance function is at the exceptionally high level so that the purchasing of the new part/repairing of the damaged one is always done in time. This idealized approach was adopted since in that way one obtains the least economic effects of the reparatory technology application with respect to replacing the part with the spare one. In any other case the economic effects would be significantly higher, namely even more positive in favor of the hard facing revitalization technology.
\end{abstract}

Key words - Revitalization technology, hard facing, costs, savings, profitability, loader's bucket teeth.

\section{Introduction}

During the exploitation of various machine parts the wear of their surfaces is inevitable. Causes of damages could be different and they were the subject of previous research of this group of authors (ARSIĆ D. et al. 2016a, ARSIĆ D. et al. 2015, LAZIĆ V. et al. 2015b, 2016), as well as others (ŽUROVSKI W. 2012 ). Considering that the damages have to be removed so that parts could be used again without any impediments, it is necessary either to replace or to repair them. The reparation of parts is seldom simple. However, as it turned out, one of the most reliable methods of parts' revitalization is hard facing. Besides the realization of favorable mechanical characteristics of the parts repaired by hard facing, significant savings of financial resources can be achieved by application of that technique.

The objective of this paper was to illustrate how the savings can be calculated and to point to additional possibilities for application of hard facing. The example for analysis of savings was hard facing reparation of the loader's bucket teeth. The complete hard facing procedure - the selection of welding parameters, filler 
metal and the heat treatments prior to and post hard facing, is presented in details in (LAZIĆ V. et al. 2014, MARKOVIĆ S. et al. 2011, MUTAVDŽIĆ M. et al. 2008, 2012).

The techno-economic justification of a certain process can be calculated and/or evaluated by various methods. The most known methods are Profitability Improvement Analysis method (PIA), Method of Economic Efficiency (MEE), the Life Cycle Cost method (LCC), Machinery and Allied Products Institute method (MAPI) and the Net Present Value method (NPV), (LAZIĆ V. et al. 2014, ARSIĆ D. et al. 2016b, WASSERMAN R. 2003, WILD J. et al. 2012). Each of those methods has its own criteria for estimates of the techno-economic justifiability of a certain technology for revitalization of the damaged machine parts. The decision is made by application of the optimal one. The same methods can be used for decision making on the optimal technology for manufacturing of the new parts, as well. Selection of the most profitable technology is done based on indicators of the economic justification. Calculations of economic effects that would be realized by application of some other reparation methods and by reparatory hard facing (RHF) belong to two different groups of economic categories. The form of the economic effects, by which the contribution of a certain technology is evaluated, must be in accordance with the criteria, which express the tendency to realize certain outcome effects (ARSIĆ D. et al. 2016b).

The economic effects of the two different technologies for renewal of various working parts are considered in this paper, namely replacing the damaged parts by the new spare parts and reparatory hard facing of the damaged parts.

When initiating the revitalization procedure of the damaged part, it must be kept in mind that this process is always restricted by different factors, the most important being availability of needed technology and of the financial resources (ARSIĆ D. ET AL 2016). What concerns the available technology, the two alternatives - to purchase the new part and to revitalize the damaged one are compared. When considering the available financial resources, on the other hand, the criterion of maximal rationality must be obeyed.

When the two technologies are being compared, the advantage should always be given to one which produces the better techno-economic effects (WILD J. et al.2012). The criteria for evaluation of investments into either of the two alternative technologies, namely to determine the amount of money to be spent, are parameters: higher profitability and absolute viability.

\section{Determination of the hard facing re- paration profitability}

In the case when the most frequently used procedures are applied as the justifiability measures for application of a certain technology, the best analysis method is the profitability of that technology. The procedures are as follows: comparison of profitability as the ratio of incomes and expenses; comparison of costs and realized savings due to those costs' decrease; increase of the financial results by income increase due to costs' decrease. In quantitative economic analysis the direct (net) gain is estimated. One has to also take into account the so-called unexpected costs, as well as internal effects and multiplication effects (LAZIĆ V. et al. 2014, ARSIĆ D. et al. 2016b, WILD J.et al. 2012). The net profit calculation goal is to express the general rationality principle if the new technology is introduced.

The costs of procuring the new part $\left(C_{n p}\right)$ represent the sum of all the costs accompanying the purchase the new part's price, the transportation costs, customs costs - if the part was imported, the VAT costs, keeping and storage costs, etc. Those costs are reduced for the amount obtained if the damaged part is sold $\left(C_{l d}\right)$. However, those costs should be increased for an amount of additional costs $\left(C_{a}\right)$ due to different reasons - downtimes in production, penalties for the overdue deliveries, etc. The costs of procuring the new part are being determined based on the company's documentation.

The analysis of the techno-economic justifiability of the reparatory hard facing of damaged machine parts according to the profitability method, performed in this paper, consisted of comparing costs of reparation to costs of replacement of the damaged parts by the new spare ones. Such partsare generally purchased and kept in a maintenance storage as spare parts. Thus, when a part is damaged in exploitation, it can be replaced by a spare one. At the same time, a damaged part is deducted and discarded. 
This analysis is also conducted under an assumption that organization of the maintenance function is at the exceptionally high level, meaning that the purchasing of the new part is always done in time. The same is assumed for reparation of the damaged part. So, it is assumed that there is always sufficient number of working parts in storage ready to be used for replacement of the damaged one. This approach is somewhat idealized. The reason why is it selected is that in such a way one obtains the least economic effects of the reparatory technology application with respect to replacing the part with a spare one, whichwould illustrate the superiority of the former technology with respect to the latter one. In any other case, those economic effects would be significantly higher, namely even more positive.

The additional costs, due to downtimes during the single replacement of the damaged part by the new or the repaired one, were not taken into account in this techno-economic analysis. Those costs are almost the same for the two technologies and do not significantly influence the final conclusion of the analysis. However, they have to be taken into account in the analysis if the larger number of replacements is done. The reason is that the new parts have shorter working life than the repaired ones, which means that the number of replacements is bigger if the parts are replaced by the new ones, than by the repaired ones. That then significantly increases the replacement costs and that strongly influences the final conclusion of the technoeconomic analysis in favor of reparation technology. Generally, the additional costs, which are pretty high, are calculated per annum. That is usually done in calculating the economic effects of a certain technology (WILD J. et al. 2012).

\section{Profitability analysis of the damaged loader's teeth reparation}

Here is presented only the techno-economic analysis of justifiability of the damaged loader's teeth reparation, while the compete procedure of the revitalization by hard facing is presented elsewhere (LAZIĆ V. et al. 2015).

The analyzed working parts are, according to the purchasing plans, procured several times per anum, i.e. the savings realized per one piece should be mulitplied by the number of replacements and thus the savings per anum would be obtaind.

The techno-economic effects were calculated according to the following parameters:

- total costs for purchasing of the new part $C_{n p}, €$;

- total costs for reparation of the damaged part $C_{r p}, €$;

- the profitability coefficient

$$
c_{e}=\left(C_{n p}-C_{r p}\right) / C_{n p} ;
$$

- the exploitation reliability coefficient:

$$
c_{\text {ex rel }}=t_{\text {erp }} / t_{\text {enp }},
$$

where $t_{e n p}$ and $t_{e r p}$ are the effective operational time of the new and repaired parts, respectively;

- the economic rationality coefficient:

$$
c_{e c \text { rat }}=\left(C_{n p} \cdot i_{h n p}\right) /\left(C_{r p} \cdot i_{h r p}\right) \text {, }
$$

where $i_{h n p}$ and $i_{h r p}$ are the limiting wear of the new and repaired part, respectively;

- total costs per/annum $C_{a n n}, €$;

- direct savings per piece $S, €$ and

- direct savings per annum $S_{a n n}, €$.

\section{Results and discussion}

The basic parameters for profitability calculation of the compared revitalization technologies of the damaged loder's teeth, shown in Figure 1, were:

- base metal - steel cast iron 50Mn7 (DIN);

- teeth mass $-8.6 \mathrm{~kg} /$ piece (average value);

- number of teeth - 10 pieces (one set);

- purchase price - $113.5 € /$ piece;

- filler metal - ABRADUR 58 and INOX B 18/8/6 (Catalogues of base and filler metals);

- purchase price $-15 € / \mathrm{kg}$;

- reparatory work price (norm hour(s)) - $10 € / \mathrm{h}$;

- applied reparation procedure - MMA welding. The parameters that are important for comparison of the two technologies were:

- exploitation time of the set of the new teeth working with stones and aggregates is, on average, $t_{\text {expnp }}=1200 \mathrm{~h}$ of effective operation (determined in authors' own experimental investigations);

- exploitation time of the surfaced teeth in the same operation conditions, on average $t_{\text {expp }}=4200 \mathrm{~h}$ (determined in authors' own experimental investigations); 
- liquidation value of the worn teeth scrapped material is $T_{l o}=0.2 € / \mathrm{kg}$;

Quality (primary and secondary) of the repaired teeth was at least the same or better than that of the new teeth.
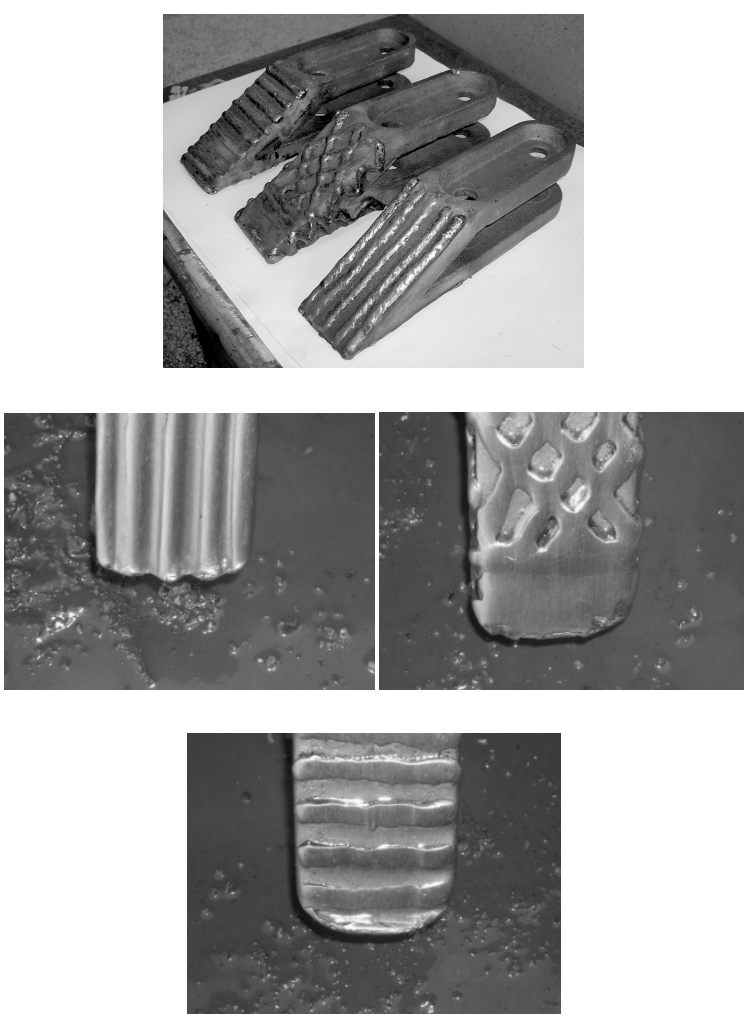

Fig. 1. The damaged (above) and repaired (below) loader's teeth.

The costs that are significant for comparison of the two technologies were:

- total costs of purchasing of one set of the new teeth $C_{n p}=1210 € ;$

- total costs of reparation of one set of worn teeth $C_{r p}=320 €$

- total costs due to downtime (losses) in present conditions for this machine amount to $C_{d t}=20 € / \mathrm{h}$.

The calculated values of all the coefficients and savings are presented in Table 1 .

Table 1. Loader's teeth revitalization

\begin{tabular}{|l|c|c|c|c|c|}
\hline $\begin{array}{c}\text { Applied } \\
\text { technology }\end{array}$ & $\begin{array}{c}C_{n p}, C_{r p} \\
€\end{array}$ & $c_{e}$ & $c_{\text {ex rel }}$ & $c_{e c}$ rat & $\begin{array}{c}C_{a n n} \\
€\end{array}$ \\
\hline Replacement & 1210 & 0.735 & 3.500 & 13.226 & 6021 \\
\hline Reparation & 320 & & \multicolumn{3}{|c|}{$S_{\text {ann }}=4961 €$} \\
\hline $\begin{array}{l}\text { Direct sav- } \\
\text { ings }\end{array}$ & \multicolumn{2}{|c|}{$S=890 €$} & \multicolumn{3}{c|}{$(82.40 \%)$} \\
\hline
\end{tabular}

From the presented results one can clearly see the superiority of the reparation technology with respect to replacement of the damaged teeth with the spare ones.

Direct savings per one set of teeth is $73.50 \%$ with respect to new parts' purchasing, while the annual savings are even bigger $(82.40 \%)$ due to larger number of teeth sets being damaged and replaced/repaired.

\section{Conclusion}

The profitability based method for calculating the savings realized by the reparation technology of the loader's bucket teeth is presented in this paper. Analysis of savings showed that the savings realized by this revitalization technique could be as high as $82 \%$ of the new parts costs, on the annual level.

Besides the direct savings, expressed in money, revitalization by hard facing also provides savings in down times of the construction mechanization, recycling of the damaged parts and above all, savings due to increased working life of the repaired part with respect to the brand new one.

According to this principle, the savings could be calculated for other machine parts that could be revitalized by hard facing, with respect to purchasing the new parts or any other revitalization technique.

\section{Acknowledgement}

This research was partially financially supported through realization of project "Research Center of the University of Žilina" - ITMS 26220220183 and grants TR 35024 and ON174004 from Serbian Ministry of Education, Science and Technological development.

\section{References}

1. ARsiĆ D., LAZIĆ V., SAMARDŽIĆ I., NiKOliĆ R., AleKSANDROVić S., DJORdJeVić M., Hadzima B., Impact of the hard facing technology and the filler metal on tribological characteristics of the hard faced forging dies, Technical Gazette, 22(5), pp. 1353-1358, 2015.

2. Arsić D., LaZiĆ V., Mitrović S., DŽUniĆ D., AlEKSANDROVIĆ S., NeDElJKOVIĆ B., DJORDJEVIĆ M. Tribological behaviour of four types of filler metals for hard facing under dry conditions, Industrial Lubrication and Tribology, 68(6), pp. 729-736, 2016 a.

3. Arsić D., LaziĆ V., Nikolić R. R., MutaVdžić M., SEDMAKA., HADZIMA B., Possibility for realizing savings by application of the hard facing as the revitaliza- 
Vukić Lazić et al., Revitalization of the damaged machine parts by hard facing ..., Vol. 12(3)/2016

tion technology of various machine parts In:Technical aspects of materials quality, Eds. J. Pietraszek, D. Klimecka-Tatar, (SMJiP), Częstochowa, Poland, pp. 111$144,2016 b$.

4. LaziĆ V., ČUKIĆ R., AleKSANDROVIĆ S., Milosavljević D., ARsić D., NedeljKović B., DJORDJEVIĆ M., Techno-economic justification of reparatory hard facing of various working parts of mechanical systems, Tribology in Industry, 36(3), pp. 287-292, 2014.

5. LAZIĆ V., ARsiĆ D., MutaVdŽIĆ M., NikOliĆ R., HADZIMA B., RATKOVIĆ N. Profitability analysis of reparation of the construction machinery damaged parts - how to save money, Proceedings of The $43^{\text {rd }}$ International Conference "Welding 2015", Tatranská Lomnica, Slovakia, 11-13 November, pp. 15-27, 2015a.

6. Lazić V., Sedmak A., Nikolić R., Mutavdzić M., AlEKSANDROVIĆ S., KRSTIĆ B., MilosavlJEVIĆ D., Selection of the most appropriate welding technology for hard facing of bucket teeth, Materiali in Tehnologije-Materials and Technologies, 49(1), pp. 165-172, $2015 b$.

7. LaZiĆ V., ARsić D., NiKolić R., MutavdžIĆ M., MEŠKO J., Reparation by hard facing of the damaged secondary stone crushers, Manufacturing Technology, 16(2), pp. 375-380, 2016.

8. Marković S., MiLOVić LJ., Marinković A., LAZOVIĆ T.,Tribological aspect of selecting filler metal for repair surfacing of gears by hard facing, Structural Integrity and Life, 11(2), pp. 127-130, 2011.
9. Mutavdžić M., ČukiĆ R., Jovanović M., MilosaVlJEVIĆ D., LAZIĆ V., Model investigations of the filler materials for regeneration of the damaged parts of the construction mechanization, Tribology in Industry, 30 (3), pp. 3-9, 2008.

10. Mutavdžić M., Lazić V., Milosavljević D., ALEKSANDROVIĆ S., NIKOLIĆ R., ČUKIĆ R., Determination of the optimal tempering temperature in hard facing of the forging dies, Materials EngineeringMaterialove Inzenierstvo, 19(3), pp. 95-103, 2012.

11. NedelJKović B., BABIĆ M., MutavdŽIĆ M., RATKOVIĆ N., ALEKSANDROVIĆ S., NIKOLIĆ R., LAZIĆ V.,Reparatory hard facing of the rotational device knives for terrain leveling, Journal of the Balkan Tribological Association, 16(1), pp. 46-57, 2008.

12. WASSERMAN, R.,How to save millions by reparatory welding in machine maintenance, Castolin Eutectic, Institute for advancement of the reparatory welding and welding techniques in machine maintenance, Technical Faculty of Bor, Bor, Serbia (Translation to Serbian). 2003.

13. Wild J., ShaW K, Chiappetta B., Fundamental accounting Principles, Mc Graw - Hill, New York, USA, 2014.

14. ŻUROWSKI W.,Structural factors contributing to increased wear resistance of steel friction couples, Eksploatacja i Niezawodnošć - Maintenance and Reliability,14(1) pp. 19-23, 2012.

15. Catalogues of base and filler metals (welding consumables): Steel plant Jesenice, Slovenia; EN Standards; DIN normen. 